\title{
Performance and Color of Broilers Fed Diets Containing Rhodocyclus gelatinosus Biomass
}

\section{Author(s)}

Ponsano EHG

Pinto MF

Garcia-Neto $M^{1}$

Lacava $\mathrm{PM}^{2}$

Professor, Departamento de Apoio, Produção e Saúde Animal

Curso de Medicina Veterinária - UNESP Campus de Araçatuba.

2 Retired professor - Instituto de Química UNESP - Campus de Araraquara.

\section{Mail Address}

Elisa Helena Giglio Ponsano

Departamento de Apoio, Produção e Saúde Animal

Medicina Veterinária - UNESP

Rua Clóvis Pestana, 793

16.050-680 - Araçatuba, SP, Brasil

E-mail: elisahgp@fmva.unesp.br

\section{Keywords}

biomass, broilers, color, performance, Rhodocyclus gelatinosus.

\section{Acknowledgements}

Authors thank Dr. Silvia Helena Venturoli Perri for statistical analysis and Fundunesp for financial support.

\section{ABSTRACT}

The objective of this study was to evaluate the effect of different supplementation levels of Rhodocyclus gelatinosus biomass on the performance and pigmentation of broilers. Cobb broilers were raised in pens and were fed a sorghum-based diet until 35 days of age. At the $36^{\text {th }}$ day of age, ninety-six birds were randomly distributed to four treatments consisting of experimental diets with different supplementation levels of Rhodocyclus gelatinosus biomass $(0,75,150$ and $300 \mathrm{ppm}$ ) added to the finisher basal diet, which were given for seven days. A completely randomized experimental design was used, with four treatments, four replicates and six broilers per parcel. Birds and diets were weighed at the $36^{\text {th }}$ and at the $42^{\text {nd }}$ day of age for performance analysis. There was no significant effect on broiler feed intake. Significant differences in weight gain and feed conversion were seen between the control group and the groups supplemented with 75 and $150 \mathrm{ppm}$. The treatment with the highest supplementation level and the control group had best weight gain and feed conversion. Color analysis showed that $R$. gelatinosus biomass supplementation resulted in more yellow breast skin and increased darkening and color purity in breast and thigh meat of broilers, but had no effect on lightness or color purity of breast and thigh skins.

\section{INTRODUCTION}

Visual appearance, especially color, is the most important characteristic of foods and determines the choice or rejection of the product by the consumer. This statement is also true for poultry products, in which the color of skin, meat and egg yolk plays a fundamental role to some ethnic and regional consumers (Chichester, 1981; Hencken, 1992; Williams, 1992; Macdougall, 1994; Franchini \& Padoa, 1996). The preference for well-pigmented poultry products is still evident in some markets, and thus poultry producers add colorants to broiler and layer diets as a means of improving the attractiveness of these products (Klaui \& Bauernfeind, 1981; Hencken, 1992; Franchini \& Padoa, 1996; Liufa et al., 1997). This practice was not necessary earlier, when the colors desired for poultry commercialization were assured by the extensive rearing methods that included enough grass and corn supply in the feed and by the non-automated slaughtering practices used in processing. Nowadays, intensive raising systems, genetic selection of fast-growing strains and the use of low-fiber diets led to smaller intake of xanthophylls and, consequently, to lower pigmentation of broiler carcasses (Marusich \& Bauernfeind, 1981; Latscha, 1990; Williams, 1992). In order to solve these problems and meet consumer demands, poultry producers increase the content of xanthophylls in the diets by adding natural or synthetic colorants. These colorants must be oxycarotenoids (xanthophylls), a 
Ponsano EHG, Pinto MF, Garcia-Neto M, Lacava PM
Performance and Color of Broilers Fed Diets Containing Rhodocyclus gelatinosus Biomass group of carotenoids that provide pigmentation due to selective deposition on different animal tissues (Klaui \& Bauernfeind, 1981; Marusich \& Bauernfeind, 1981; Latscha, 1990; Hencken, 1992; Franchini \& Padoa, 1996; Liufa et al., 1997). The synthetic pigment apocarotenoic acid ethyl ester (APO-EE), commercially available as Carophyll Yellow ${ }^{\circledR}$, imparts yellowish color to broilers skin and, despite the high cost, it is still the most widely used pigment for this purpose due to its high pigmenting ability and resistance to oxidation (Marusich \& Bauernfeind, 1981; Latscha, 1990; Franchini \& Padoa, 1996). The choice of the pigment to be added to diets depends on the demands of the food industry and consumers. Nowadays, there is a tendency to use natural products (Franchini \& Padoa, 1996). Therefore, new oxycarotenoids isolated from plants, algae and specific microorganisms have been tested as feed ingredients and showed good results (Gierhart, 2002; Gouveia et al., 1996; Cruz \& Parajó, 1998; Vazquez \& Martin, 1999; Martin \& Sivagurunathan, 1999; Del Campo et al., 2000; Martin \& Sivagurunathan, 2000; Ponsano, 2000; Pérez-Vendrell et al., 2001; Lorenz, 2002 a, b; Ponsano et al. 2002 a,b). Oxycarotenoids produced by microorganisms may be used as biomass or purified. The microbial biomass has not only the pigmenting potential, but also contains proteins, minerals and vitamins that may be beneficial to animals when added to the feed (Balloni et al., 1982; Noparatnaraporn et al., 1983).

Recent trials carried out with Rhodocyclus gelatinosus biomass produced in industrial wastewater showed the positive effect of this product on broiler pigmentation measured with the spectrophotometric CIELCh color scale (Ponsano, 2000; Ponsano et al., 2002a). The CIE LCh system defines color as a threedimensional characteristic consisting of a lightness attribute and two chromatic attributes named hue and chroma. Hue ( $h$ ) is the attribute of color perception by which an object is judged to be red, yellow, green, blue and so forth. It may be measured by means of an angle scale in which the starting point $0^{\circ}$ is assigned to red and $90^{\circ}$ is assigned to yellow. The attribute chroma (C) designates color concentration, saturation or purity. The scale varies from zero to 60 , in which high values are assigned to higher color intensity. Lightness $\left(L^{*}\right)$ is the attribute that distinguishes light colors from dark colors, and the scale ranges from zero, which represents black, to 100 , which represents white $(\mathrm{CIE}$, 1986). Diets tested in those studies were prepared with corn and corn gluten meal, which might cause an additional increase in pigmentation. In the present study, diets were formulated with sorghum, which is free of oxycarotenoids, in order to eliminate possible interferences from other ingredients and to better evaluate whether $R$. gelatinosus biomass administration may effectively lead to changes in hue, lightness and saturation of skin and meat color of broilers. The effects of dietary inclusion of Rhodocyclus gelatinosus biomass on bird live performance have not been evaluated in the previous studies due to logistical constraints in the commercial plant where they were carried out. Additionally, besides the oxycarotenoids, that confer red color on $R$. gelatinosus biomass, the product contains (on a wet basis) $62.8 \%$ proteins, $25.6 \%$ carbohydrates, $0.5 \%$ lipids and $4.0 \%$ ash and all amino acids that are essential for birds, nutrients that might have a positive effect on broiler nutrition (Ponsano et al., 2003). Therefore, elucidations on the pigmenting and nutritional potential of $R$. gelatinosus biomass for broilers are still necessary.

The present study was performed to evaluate the influence of different inclusion levels of Rhodocyclus gelatinosus biomass in diets on broiler performance and pigmentation.

\section{MATERIAL AND METHODS}

\section{Broilers and housing}

Cobb x Cobb one-day-old male broiler chicks were raised together from one to seven days of age in a 1.5 $\times 3.0 \mathrm{~m}$ pen equipped with feeders and drinkers and heating was provided 24 hours (infra-red lamps, 250 Watts). From eight to twenty-one days of age, birds were allocated in two pens and heating was provided only during the night. In the first three weeks, starter diet (Table 1) and water were given ad libitum. From twenty-two to twenty-eight days of age, birds were distributed in four pens and, from twenty-nine to thirtyfive days, they were randomly redistributed in 16 pens (six birds per pen). During this second period of two weeks, broilers were fed grower diet (Table 1) and water ad libitum.

\section{Experimental design and treatments}

The sixteen pens (six birds/pen) were randomly assigned to each of the four treatments when birds were 36 days old. Treatments consisted in the administration of different levels of Rhodocyclus gelatinosus biomass $(0,75,150$ and 300 ppm) added to the finisher (basal) diet (Table 1) during seven days. Experimental diets were supplied once $(1,100 \mathrm{~g}$ per broiler) at the thirty-sixth day of the experiment. Four replicates were used. 
Ponsano EHG, Pinto MF, Garcia-Neto M, Lacava PM
Table 1 - Composition of experimental diets.

\begin{tabular}{|c|c|c|c|}
\hline Ingredient (\%) & $\begin{array}{c}\text { Starter } \\
\text { (1-21 days) (2 }\end{array}$ & $\begin{array}{l}\text { Grower } \\
2-35 \text { days) (36 }\end{array}$ & $\begin{array}{r}\text { Finisher } \\
\text { 6-42 days) }\end{array}$ \\
\hline Sorghum & 52.11 & 61.66 & 68.08 \\
\hline Soybean meal (48\%) & 37.50 & 29.63 & 24.42 \\
\hline Soybean oil & 6.93 & 5.68 & 4.82 \\
\hline Dicalcium phosphate & 2.04 & 1.83 & 1.63 \\
\hline Limestone & 0.60 & 0.56 & 0.54 \\
\hline $\mathrm{NaCl}$ & 0.213 & 0.115 & 0.066 \\
\hline DL methionine & 0.208 & 0.110 & 0.047 \\
\hline L-lysine $\mathrm{HCl}$ & 0.007 & 0.021 & - \\
\hline Vitamin-mineral premix ${ }^{1}$ & 0.40 & 0.40 & 0.40 \\
\hline \multicolumn{4}{|c|}{ Calculated Analysis } \\
\hline Metabolizable energy ( $\mathrm{kcal} / \mathrm{kg}$ ) & ) 3,200 & 3,200 & 3,200 \\
\hline Crude protein (\%) & 23.00 & 20.00 & 18.00 \\
\hline Calcium (\%) & 1.000 & 0.900 & 0.813 \\
\hline Available phosphorus (\%) & 0.500 & 0.450 & 0.406 \\
\hline Sodium (\%) & 0.200 & 0.150 & 0.120 \\
\hline Methionine (\%) & 0.538 & 0.402 & 0.318 \\
\hline Methionine + cystine (\%) & 0.897 & 0.720 & 0.610 \\
\hline Lysine (\%) & 1.229 & 1.028 & 0.873 \\
\hline \multicolumn{4}{|c|}{$\begin{array}{l}1 \text { - Provided per } \mathrm{kg} \text { of diet: vitamin } \mathrm{A}, 8,800 \mathrm{IU} \text {; vitamin } \mathrm{D}_{3}, 3,300 \mathrm{IU} \text {; } \\
\text { vitamin } \mathrm{E}, 40 \mathrm{IU} \text {; vitamin } \mathrm{K}_{3}, 3.3 \mathrm{mg} \text {; thiamine, } 4.0 \mathrm{mg} \text {; riboflavin, } 8.0 \\
\mathrm{mg} \text {; pantothenic acid, } 15 \mathrm{mg} \text {; niacin, } 50 \mathrm{mg} \text {; pyridoxine, } 3.3 \mathrm{mg} ; \\
\text { choline, } 600 \mathrm{mg} \text {; folic acid, } 1 \mathrm{mg} \text {; biotin, } 220 \mathrm{mg} \text {; vitamin } \mathrm{B}_{12}, 12 \mathrm{mg} \text {; } \\
\text { antioxidant, } 120 \mathrm{mg} \text {; manganese, } 70 \mathrm{mg} ; \text { zinc, } 70 \mathrm{mg} \text {; iron, } 60 \mathrm{mg} \text {; } \\
\text { copper, } 10 \mathrm{mg} \text {; iodine, } 1.0 \mathrm{mg} \text {; selenium, } 0.3 \mathrm{mg} \text {. }\end{array}$} \\
\hline
\end{tabular}

\section{Experimental diets}

Diets were prepared according to NRC recommendations (NRC, 1994) and stored in closed plastic vats at room temperature. Lyophilized Salmonella-free Rhodocyclus gelatinosus biomass containing oxycarotenoids of the alternative spirilloxanthin series was produced in poultry slaughterhouse wastewater as described by Ponsano et al. (2003). For the preparation of diets, each different concentration of biomass $(75,150,300$ ppm) was added to five $\mathrm{kg}$ of the finisher diet and mixed in a Y-type mixer for $10 \mathrm{~min}$. Afterwards, each mixture was added to the remaining finisher diet and mixed for $10 \mathrm{~min}$ in a horizontal mixer.

\section{Processing procedures}

Twelve broilers from each treatment were randomly selected for processing in a commercial slaughter plant. Chickens were stunned in a 90-V water stunning bath for $2 \mathrm{~s}$, bled for $3 \mathrm{~min}$ by severing the jugular veins, scalded in hot water for 2 min and defeathered in an automated picker. Birds were automatically eviscerated, chilled in an ice bath spin-chiller for 45 min and drained for approximately $10 \mathrm{~min}$ to reduce moisture retention to $8 \%$ (Brasil, 1997). Carcasses were then packaged into plastic bags and held at $-20^{\circ} \mathrm{C}( \pm$ $1^{\circ} \mathrm{C}$ ) for seven days until analysis.
Performance and Color of Broilers Fed Diets Containing Rhodocyclus gelatinosus Biomass

\section{Evaluated parameters}

Feed intake, weight gain and feed conversion data were determined from broiler and feed weights recorded at the beginning (36 d) and at the end of the experiment (42 d) (Torres, 1977). For the color analysis, carcasses were taken out of the bags and rinsed thoroughly with tap water. Breast and thigh skins were raised up carefully. Carcasses were covered with a dry transparent film and the color attributes lightness $\left(\mathrm{L}^{*}\right)$, chroma (C) and hue (h) were measured four times on the surface of the skin and the meat of breast and thigh. A Hunter Lab spectrophotometer model Color Quest II was used, calibrated with white standard (C6299 - Date 03/96 - X 77.46 - Y 82.08 - Z 88.38) and gray standard (C6299G - Date 03/96-X 47.71 - Y 50.83 - Z 54.94). Measurements were performed using 1 inch viewing area aperture, $D_{65}$ illuminant and $10^{\circ}$ observer, according to $\mathrm{CIE}$ recommendations (CIE, 1986). Although freezing may change color results, this procedure was necessary since color measurements could not be performed soon after slaughtering because of the number of birds and the great distance between the slaughtering plant and the laboratory. Alterations resulting from freezing were not considered in any treatment.

\section{Statistical analysis}

Performance and color data were analyzed by ANOVA and means were compared using the Duncan's Test according to Zar (1984). Data were processed by SAS (1998).

\section{RESULTS AND DISCUSSION}

Broiler performance data are presented in Table 2. Feed intake was not significantly different $(p>0.05)$ among treatments. The control group and the group fed the highest biomass concentration (300 ppm) had the highest weight gain and, consequently, the best feed conversion was also seen in these groups. Treatments that supplied lower levels of biomass (75 and $150 \mathrm{ppm}$ ) showed lower weight gain and worse feed conversion, that were considered statistically similar ( $p>0.05)$. Liufa et al. (1997) reported that broiler performance was not adversely affected when birds were fed different sources of xanthophylls, such as Alocacia leaf meal, saponified carotenoid mixture, a preparation of microencapsulated carotenoids, Carophyll Yellow $^{\circledR}$, Carophyll Red ${ }^{\circledR}$ or yellow corn. Akiba et al. (2001) evaluated the effect of Phaffia rhodozyma yeast added to the diet on meat color of broiler chickens 
and reported no significant effects on performance with non-supplemented diets or diets supplemented with non-treated yeast or cell-wall fractured yeast. Pérez-Vendrell et al. (2001) studied the influence of dietary inclusion of chemically isomerized marigold, conventional marigold and canthaxanthin on broiler chicken pigmentation and performance and found no significant effects of treatments on chicken performance. As live performance parameters were not investigated in previous studies conducted with $R$. gelatinosus biomass (Ponsano, 2000; Ponsano et al., 2002a), comparison with the present data is not possible. However, the performance results observed in the present trial for the higher biomass supplementation level emphasize the need for further investigations with biomass levels higher than 300 ppm and/or for longer administration time, so that the possible benefits of the product can be better evaluated.

Table 2 - Performance of broilers fed diets containing different levels of R. gelatinosus biomass ( $36-42$ days).

\begin{tabular}{lccc} 
Treatment & $\begin{array}{c}\text { Feed Intake } \\
(\mathbf{g})(\overline{\mathbf{X}} \pm \mathbf{s})\end{array}$ & $\begin{array}{c}\text { Weight Gain } \\
\mathbf{( g )}(\overline{\mathbf{X}} \pm \mathbf{s})\end{array}$ & $\begin{array}{c}\text { Feed Conversion } \\
(\mathbf{g} / \mathbf{g})(\overline{\mathbf{X}} \pm \mathbf{s})\end{array}$ \\
\hline Control & $902 \pm 34 \mathrm{a}$ & $412 \pm 41 \mathrm{a}$ & $2.19 \pm 0.31 \mathrm{~b}$ \\
$75 \mathrm{ppm}$ & $911 \pm 10 \mathrm{a}$ & $361 \pm 14 \mathrm{bc}$ & $2.53 \pm 0.11 \mathrm{a}$ \\
$150 \mathrm{ppm}$ & $906 \pm 24 \mathrm{a}$ & $351 \pm 10 \mathrm{c}$ & $2.58 \pm 0.08 \mathrm{a}$ \\
$300 \mathrm{ppm}$ & $926 \pm 5 \mathrm{a}$ & $397 \pm 18 \mathrm{ab}$ & $2.33 \pm 0.09 \mathrm{ab}$ \\
Pr $>\mathrm{F}$ & 0.5492 & 0.0146 & 0.0532 \\
$\mathrm{CV} \%$ & 2.45 & 6.44 & 7.50 \\
\hline $\mathrm{a}, \mathrm{b}, \mathrm{c}-$ Means in a column with different superscripts differ
\end{tabular}
significantly $(p<0.05)$. by Duncan's test. CV - Coefficient of variation.

Table 3 presents the results of color attributes found on the surfaces of breast and thigh skin. The levels of $R$. gelatinosus biomass tested in this experiment resulted in no significant darkening of the breast or thigh skin $(p>0.05)$. Besides, no significant change ( $p>0.05)$ was caused by treatments on thigh skin hue values. On the other hand, evident results on this attribute were observed in breast skin. The increase in biomass concentration provided more yellow hues that were significantly different from the control group $(p<0.05)$. In the experiment conducted by Akiba et al. (2001), the dietary inclusion of Phaffia rhodozyma cells in broiler diets had no effects on $L^{*}$ or yellowness of breast skin. Ponsano et al. (2002a) studied the influence of $R$. gelatinosus biomass added to broiler diets formulated with corn and corn gluten meal on skin and meat pigmentation of breast and thigh. Darker colors were reported for breast and thigh skin when compared to the findings of the present study. Although different levels of biomass were used in the two experiments, the difference in color is probably due to the presence of oxycarotenoids in the basal diets of the first experiment. Corroborating the data presented herein, Ponsano et al. (2002a) reported more yellow hues on the breast skin and also verified that increases in biomass concentration caused no significant increases on chroma values of the breast and thigh. In the present experiment, increasing biomass levels had no significant effect on chroma values of thigh skin ( $p>0.05)$. Furthermore, only the treatment that supplied the lowest biomass concentration provided a significantly lower chroma value of breast skin $(p<0.05)$.

Color attributes of breast and thigh meat are presented in Table 4. Each increase in $R$. gelatinosus biomass concentration resulted in darkening of the breast and thigh meat. Breast meat was darker $(p<0.05)$ in the highest biomass supplementation level (300 ppm) compared to the control group, and thigh meat darkening was significantly different $(p<0.05)$ among the groups supplemented with 150 and 300 ppm of biomass and control. Hues were redder on breast and thigh meat compared to skin, although no

Table 3 - Color attributes ( $L^{*}$ - lightness, C - chroma, $\mathrm{h}$ - hue) for breast and thigh skin of broilers fed diets containing different levels of $R$. gelatinosus biomass.

\begin{tabular}{|c|c|c|c|c|c|c|}
\hline \multirow{3}{*}{$\begin{array}{l}\text { Evaluated Parameter } \\
\text { Treatment }\end{array}$} & \multicolumn{6}{|c|}{ Color } \\
\hline & \multicolumn{3}{|c|}{ Breast Skin } & \multicolumn{3}{|c|}{ Thigh Skin } \\
\hline & $L^{*}(\bar{X} \pm s)$ & $C(\bar{x} \pm s)$ & $\overline{h(\bar{X} \pm s)}$ & $L^{*}( \pm S)$ & $C(\bar{x} \pm s)$ & $\overline{h(\bar{X} \pm s)}$ \\
\hline Control & $73.93 \pm 1.52^{a}$ & $14.56 \pm 0.87^{a}$ & $76.45 \pm 1.63^{b}$ & $73.18 \pm 4.63^{a}$ & $10.20 \pm 1.67^{a}$ & $76.03 \pm 2.74^{a}$ \\
\hline 75 ppm & $72.70 \pm 1.87^{a}$ & $9.99 \pm 2.98^{b}$ & $80.14 \pm 1.75^{a}$ & $72.77 \pm 1.58^{a}$ & $6.75 \pm 0.48^{a}$ & $76.09 \pm 3.99^{\mathrm{a}}$ \\
\hline 150 ppm & $72.35 \pm 1.69^{a}$ & $14.04 \pm 0.50^{a}$ & $77.55 \pm 1.15^{a b}$ & $73.12 \pm 1.40^{a}$ & $9.67 \pm 4.31^{a}$ & $76.53 \pm 3.62^{a}$ \\
\hline 300 ppm & $72.23 \pm 1.09^{a}$ & $14.55 \pm 2.85^{a}$ & $81.10 \pm 3.63^{a}$ & $72.95 \pm 1.45^{a}$ & $9.10 \pm 2.25^{a}$ & $79.13 \pm 1.79^{a}$ \\
\hline $\mathrm{Pr}>\mathrm{F}$ & 0.4325 & 0.0272 & 0.0418 & 0.9961 & 0.2934 & 0.4820 \\
\hline$C \vee \%$ & 2.16 & 15.97 & 2.85 & 3.62 & 28.91 & 4.10 \\
\hline
\end{tabular}

$\mathrm{a}, \mathrm{b}$ - Means in a column with different superscripts differ significantly $(\mathrm{p}<0.05)$ by Duncan's test. CV - Coefficient of variation. 


\begin{tabular}{|c|c|c|c|c|c|c|}
\hline \multirow{3}{*}{$\begin{array}{l}\text { Evaluated Paramete } \\
\text { Treatment }\end{array}$} & \multicolumn{6}{|c|}{ Color } \\
\hline & \multicolumn{3}{|c|}{ Breast Meat } & \multicolumn{3}{|c|}{ Thigh Meat } \\
\hline & $L^{*}(\bar{X} \pm s)$ & $C(\bar{X} \pm s)$ & $h(\bar{X} \pm s)$ & $L^{*}(\bar{X} \pm s)$ & $C(\bar{X} \pm s)$ & $h(\bar{X} \pm s)$ \\
\hline Control & $60.56 \pm 0.71^{a}$ & $11.25 \pm 1.07^{b}$ & $68.52 \pm 1.90^{a}$ & $63.83 \pm 0.24^{a}$ & $9.98 \pm 0.60^{c}$ & $62.47 \pm 5.47$ \\
\hline 75 ppm & $59.64 \pm 0.95^{\circ}$ & $9.88 \pm 1.17^{\circ}$ & $71.06 \pm 2.59^{\mathrm{a}}$ & $62.57 \pm 1.42^{a b}$ & $9.85 \pm 0.65^{c}$ & $66.68 \pm 6.04$ \\
\hline 150 ppm & $58.62 \pm 2.20^{a}$ & $13.61 \pm 1.05^{\mathrm{a}}$ & $70.70 \pm 3.98^{\circ}$ & $61.78 \pm 1.08^{b}$ & $11.04 \pm 0.74$ & $65.44 \pm 2.14$ \\
\hline 300 ppm & $56.72 \pm 1.16^{b}$ & $14.06 \pm 0.50^{\mathrm{a}}$ & $70.34 \pm 2.50^{a}$ & $59.96 \pm 0.27$ & $12.09 \pm 0.25$ & $63.51 \pm 2.17$ \\
\hline $\mathrm{Pr}>\mathrm{F}$ & 0.0116 & 0.0002 & 0.6118 & 0.0005 & 0.0005 & 0.5401 \\
\hline CV \% & 2.34 & 8.06 & 4.06 & 1.47 & 5.51 & 6.74 \\
\hline
\end{tabular}

a, b, c - Means in a column with different superscripts differ significantly $(p<0.05)$ by Duncan's test. CV - Coefficient of variation.

statistically significant effects ( $p>0.05)$ were observed between treatments. It is possible that these results were affected by an interaction between meat natural pigments and the biomass oxycarotenoids. Akiba et al. (2001) showed the feasibility of manipulating broiler meat color, especially breast meat, when standard and low-carotenoid diets were supplemented with Phaffia rhodozyma cells. It was reported an increase in the redness of breast and thigh meat, with no significant changes in the $L^{*}$ parameter. In the study conducted by Ponsano et al. (2002a), the addition of R. gelatinosus biomass in broiler diets formulated with corn and corn gluten meal caused the darkening of breast and thigh meat. Results also showed redder hues on breast and thigh meat of birds that received biomass supplementation, although the increases in biomass concentration caused no significant increases in breast or thigh chroma values. In this experiment, increases in biomass concentration led to significant increases $(p<0.05)$ in color purity both in breast and thigh meat when compared to the control group, except for the 75-ppm treatment.

The use of these alternative oxycarotenoids in appropriate concentrations in broiler feeds allows to substitute the synthetic pigments that generally represent high costs to producers. In Brazil, some poultry producers add Carophyll Yellow ${ }^{\circledR}$ to broiler diets in an attempt to enhance carcass pigmentation and meet preferences of some regional markets. Ponsano (2000) compared color attributes of meat and skin of the breast and thigh of broilers fed different levels of R. gelatinosus biomass, Carophyll Yellow ${ }^{\circledR}$ and Carophyll Red ${ }^{\circledR}$. Results showed that meat and skin hues of the breast and thigh of broilers fed the biomass tended to yellow, whereas treatments with synthetic pigments resulted in redder ones. All treatments increased color saturation, this effect was more evident in breast meat. According to Liufa et al. (1997), the
Chinese government spends substantial amounts with synthetic pigment Carophyll Yellow ${ }^{\circledR}$ because of consumer preferences for color in poultry carcasses. Alocasia macrorrhiza leaf meal was evaluated as a xanthophyll source for broiler pigmentation and both the leaf extract and its products were effective in pigmenting broilers, although less than Carophyll Yellow ${ }^{\circledR}$ (Liufa et al., 1997).

\section{CONCLUSIONS}

Feed intake was not affected by treatments, whereas best weight gain and feed conversion were seen in the control group and the group supplemented with the highest level of $R$. gelatinosus biomass (300 ppm). Breast and thigh skin showed more yellow hues whereas breast and thigh meat showed redder hues for all treatments. R. gelatinosus biomass administration caused increased darkening and color purity in breast and thigh meat and an intensification on the yellow hue of breast skin.

\section{REFERENCES}

Akiba Y, Sato K, Takahashi K, Matsushita K, Komiyama H, Tsunekawa $\mathrm{H}$, Nagao $\mathrm{H}$. Meat color modification in broiler chickens by feeding yeast Phaffia rhodozyma containing high concentrations of astaxanthin. Journal of Applied Poultry Research 2001; 10:154-161.

Balloni W, Materassi C, Filpi C, Sili M, Vincenzini AE, Florenzano G. II metodo di trattamento a batteri fotosintetici delle acque di scarico. Firenze: Progetto Finalizzato CNR Promocione della Qualitá dell'Ambiente; 1982. 205 p.

Brasil. Ministério da Agricultura. Decreto lei n² 2244, 5 jun., 1997. Regulamento da Inspeção Industrial e Sanitária de Produtos de Origem Animal. Brasília; 1997.

Chichester OO. Carotenoids as colorants and vitamin A precursors. In: Bauernfeind JC, editor. Carotenoids as colorants and vitamin A precursors. New York (NY): Academic Press; 1981. p. 15. 
CIE. Colorimetry. $2^{\text {nd }}$ ed. Viena: Commission Internationale de I'Eclairage; 1986.

Cruz JM, Parajó JC. Improved astaxanthin production by Xanthophyllomyces dendrorhous growing on enzymatic wood hydrolysates containing glucose and cellobiose. Food Chemistry 1998; 63:479-484.

Del Campo JA, Moreno J, Rodríguez H, Angeles Vargas M, Rivas J, Guerrero MG. Carotenoid content of chlorophycean microalgae: factors determining lutein accumulation in Muriellopsis sp. (Chlorophyta). Journal of Biotechnology 2000; 76:51-9.

Franchini A, Padoa E. I pigmenti nell'alimentazione del pollo da carne. Rivista di Avicoltura 1996; 65:22-30.

Gierhart DL. Production of zeaxanthin and zeaxanthin-containing compositions. (High Ridge, MO) Patent number 05308759. [Acessed feb.15, 2002]. Available at: http://www.nal.usda.gov/bic/ biotech_Patents/1994patents/05308759.html

Gouveia L, Veloso V, Reis A, Fernandes H, Novais J, Empis J. Chlorella vulgaris used to colour egg yolk. Journal of Sciences in Food Agriculture 1996; 10:167-172.

Hencken $\mathrm{H}$. Chemical and physiological behavior of feed carotenoids and their effects on pigmentation. Poultry Science 1992; 71:7117.

Klaui H, Bauernfeind JC. Carotenoids as food colors. In: Bauernfeind JC, editor. Carotenoids as colorants and vitamin A precursors. New York (NY): Academic Press; 1981; p. 47-319.

Latscha T. Carotenoids in Animal Nutrition. Basel: F. Hoffmann-La Roche; 1990.

Liufa W, Xufang L, Cheng Z. Carotenoids from Alocasia leaf meal as xanthophyll sources for broiler pigmentation. Tropical Science 1997; 37:116-122.

Lorenz RT. A review of Spirulina and Haematococcus algae meal as a carotenoid and vitamin supplement for poultry. Bulletin 053. [Accessed Feb. 15, 2002a) Available at: http://www.cyanotech.com/ pdfs/spbul53.pdf

Lorenz RT. Naturose ${ }^{\text {TM }}$ natural astaxanthin (Haematococcus algae meal) as a carotenoid and vitamin source for salmonids. Bulletin 055. [Acessed feb.6, 2002b]. Available at: <http://www.cyanotech. $\mathrm{com} / \mathrm{pdfs} / \mathrm{axbul55} . \mathrm{pdf}>$

Macdougall DB. Colour of meat. In: Pearson AM, Dutson TR. editors. Quality attributes and their measurements in meat, poultry and fish products. Glasgow: Blackie Academic \& Professional; 1994. p. 79-93.

Martin AM, Sivagurunathan M. Studies on the growth of the carotenoid producing yeast Phaffia rhodozyma in peat hydrolysateseffect of bitumen fraction on biomass productivity and yield. In: Proceedings of the Annual Meeting IFT; 1999; Chicago: IFT. [Accessed Feb. 15, 2002a]. Available at: <http://www.confex.com/ ift/99annual/ abstracts/3504.htm>
Martin AM, Sivagurunathan M. Optimization of the carotenoid production of the yeast Phaffia rhodozyma. In: Proceedings of the Annual Meeting IFT; 2000; Dallas:IFT. [Accessed Feb. 15, 2002b] Available at: <http://ift.confex.com/ift/2000/techprogram/ paper_1803.htm>

Marusich WL, Bauernfeind JC. Oxycarotenoids in poultry pigmentation. In: Bauernfeind JC, editor. Carotenoids as colorants and vitamin A precursors. New York (NY): Academic Press; 1981. p. 319-462.

Noparatnaraporn N, Nishizawa Y, Hayashi M, Nagai S. Single cell protein production from cassava starch by Rhodopseudomonas gelatinosa. Journal of Fermentation Technology 1983; 61:515-9.

NRC. National Research Council. Nutrient requirements of poultry. $9^{\text {th }}$ ed. Washington (DC): National Academy Press; 1994. 155 p.

Pérez-Vendrell AM, Hernández JM, Llauradó L, Schierle J, Brufau J. Influence of source and ratio of xanthophyll pigments on broiler chicken pigmentation and performance. Poultry Science 2001; 80:320-6.

Ponsano EHG. Avaliação da capacidade pigmentante de biomassa de Rhodocyclus gelatinosus em frangos de corte. [Tese]. Araraquara (SP): Universidade Estadual Paulista; 2000. 93p.

Ponsano EHG, Pinto MF, Garcia Neto M, Lacava PM. Evaluation of Rhodocyclus gelatinosus biomass for broiler pigmentation. Journal of Applied Poultry Research 2002a; 11:77-82.

Ponsano EHG, Lacava PM, Pinto MF. Isolation of Rhodocyclus gelatinosus from poultry slaughterhouse wastewater. Brazilian Archives of Biology and Technology 2002b; 45(4):445-9.

Ponsano EHG, Lacava PM, Pinto, MF. Chemical composition of Rhodocyclus gelatinosus biomass produced in poultry slaughterhouse wastewater. Brazilian Archives of Biology and Technology 2003; 46(2):143-7.

SAS Institute. SAS ${ }^{\circledR}$ (Statistical Analysis System). User's Guide: Statistics. Cary, NC: SAS Institute INC; 1998.

Torres AP. Alimentos e nutrição das aves domésticas. São Paulo: Nobel; 1977. 324p.

Vazquez M, Martin AM. Optimization of the biomass productivity of the carotenoid-producing yeast Phaffia rhodozyma. In: Proceedings of the Annual Meeting IFT; 1999; Chicago: IFT. [Accessed Feb. 15, 2002]. Available at: <http://www.confex.com/ift/ 98annual/accepted/35.htm>

Williams WD. Origin and impact of color on consumer preference for food. Poultry Science 1992; 71:744-6.

Zar JH. Biostatistical analysis. $2^{\text {nd }}$ ed. Englewood Cliffs: Prentice Hall International; 1984. 718 p. 